\title{
Features of Staffing for a High-tech Industrial Enterprise: Problems and Solutions
}

\author{
Elena N. Vetrova ${ }^{1}$, Galiya R. Khakimova ${ }^{2}$, \\ Aleksandr G. Komarov ${ }^{3}$ \\ Saint-Petersburg State University of Economics \\ Saint-Petersburg, Russia \\ 1vetrovaelenik@gmail.com, 2haki10@mail.ru, \\ alex.komarov64@mail.ru
}

\author{
Anton A. Vashchillo \\ PJSC "Svetlana" \\ St. Petersburg, Russia \\ a.vashchillo@svetlanajsc.ru
}

\begin{abstract}
The education system is becoming global in nature, covering not only the traditional exchange of students and teachers, but also issues of cross-border investment and competition of universities in the global educational services market, participation and (or) initiation by employers of new educational programs, considering the changing requirements of professional standards, etc. A modern industrial enterprise is high-tech and the role of the technological factor is increasing. This makes special demands on his staffing. The existing education system often lags the increasing pace of technological change. This is due to both the conservatism of the system and its personnel, material and technical and information support. Therefore, the problems of training young specialists for the modern labor market are being updated. The purpose of the study: to identify the problems of the modern labor market for a high-tech enterprise and propose a solution to these problems based on increased interaction between these enterprises and educational institutions. Methodology: systemic, strategic, comparative and statistical analysis, questioning method.
\end{abstract}

Key words - high-tech enterprise; educational program; technological changes; staffing; interaction problems; strategy

\section{INTRODUCTION}

The labor market is changing in modern conditions, which is associated with the increasing role of technological factors that change the structure of the economy and the structure of employment in the economy. The education system is more conservative, on the one hand, but at the same time often ahead of the labor market, on the other hand, not flexible enough, it does not always cope with its tasks. Therefore, coordinated actions of the high-tech sector of the economy and educational institutions in matters of personnel training are needed. As the educational system expands and becomes global, covering not only the traditional exchange of students and teachers, but also the issues of cross-border investment and competition of universities in the global educational services market, all participants in this process should reconsider their views on priorities and expected results [1]. With an actively changing technological mode, the gerontological factor has a significant impact on the dynamics of development, especially when implementing innovative strategies.
For technical universities, the problem of training is solved through the creation and active functioning of specialized departments at leading educational institutions. This allows enterprises to engage their specialists, from developers to chief engineers, in the educational process, to provide students with the opportunity to solve practical problems from the first year. For students who wish to take part in innovative development, students in the areas of economics and management have developed a certain informational vacuum that impedes their proper professional orientation. In this paper, the authors present the results of their research, their own conclusions and suggestions on this issue.

\section{METHODOLOGY}

As the information base of the research, scientific works in the field of developing the education system [1], training for the economy at the master's level [2,3], statistical data on the development of the high-tech sector of the Russian economy and its staffing [4], own observations and studies were used authors on the issues [5, 6].

These statistics show a decrease in the innovative activity of Russian companies with an increase in the share of hightech enterprises in the market, and, accordingly, in the number of high-tech jobs, but this is very insignificant compared to the advanced world level, borrowed, in most cases, foreign developments are used at domestic enterprises [4]. The reasons for this situation, among other things, are the insufficient interest of graduates of educational institutions to work at high-tech enterprises of the Russian Federation.

The need for changes in the educational process is noted by most interested participants in this process. Discussions about the effectiveness of education show a significant emphasis on its assessment, often by individual methods, for example, the model of M. Boldridge and OCAI [2], is not always justified for use, with a high subjectivity of the assessment itself. The problems of the prospects for the development of education are discussed at the level of problems of regulatory support of possible ways of this development [3], the rationale for lifelong learning [4], illustrations of unsuccessful experiments [5], or solutions to existing problems of interaction [6]. We have not identified systematic works linking the opinions of all participants in the educational process and the labor market. This 
article presents the results of a study by the authors based on surveys of various participants: students, teachers, employers, and management consultants. The study was conducted in two stages: questioning and discussion of the results with all participants together and separately.

\section{RESEACH}

The goal of a modern sustainable industrial enterprise is not only effective production activities for the creation and sale of products, but also in the development and implementation of a strategy that determines its place in the market. In most cases, we are talking about: a) the implementation of innovative projects aimed at developing and increasing the output of competitive products and services; b) the development of innovative potential, the formation of an innovatively susceptible environment and innovative culture.

With regard to the possible career guidance of students in areas of economics and management, we can talk about options for choosing the direction of educational and extracurricular activities. To understand the existing problems and ways to solve them, we developed a questionnaire and conducted a survey of interested market participants: students, employers, teachers and consultants, and obtained certain results.

In our study, we used the following types of innovations: product, organizational, technical, capital-saving and social. These types of innovations determine vocational guidance, and, accordingly, the choice of training profile.

A survey of students revealed their need for employers to participate in the learning process (more than 80\%). Various forms of participation were offered by students: guest lectures, master classes, excursions, company training, an increase in practical classes, etc.

From the point of view of employers, the proposals for interaction are as follows: the development of basic departments, the selection of students for immersion in the professional environment in the process of joint events, participation in the admission campaign and various types of certification, joint development and updating of educational programs.

The teaching staff noted the importance of enhancing interaction with employers in various areas, but at the same time, the inflexibility of existing educational standards and their own lack of motivation in this process.

The consultants, guided by the world experience in the interaction of educational institutions with employers, put in the first place the development and implementation of joint educational programs. sults.

The second stage of our study was a discussion of the re-

All survey participants agreed with our offer on career guidance for students - in the framework of educational practice or the discipline "Introduction to the specialty", take a questionnaire or write an essay on various types of innovations and their implementation in the market. This should help students to determine the profile of training in a timely manner. In addition, it will be interesting to show them these results at the beginning of training and in their choice of the theme of final works.

The participants in our study agreed on the demand for areas in relation to the given ranking of innovations (Table 1). A two-level education system allows undergraduate students, having gained a certain basic level of knowledge, to consciously stop before choosing a master's program.

TABLE I. THE RATIO OF THE DIRECTIONS AND TYPES OF INNOVATION

\begin{tabular}{|l|l|l|l|l|}
\hline $\begin{array}{l}\text { Innovations / } \\
\text { Functionality }\end{array}$ & productive & $\begin{array}{l}\text { organizational } \\
\text { and technical }\end{array}$ & capital-saving & social \\
\hline Economy & +++ & +++ & ++ & + \\
\hline $\begin{array}{l}\text { Managemen } \\
\text { t }\end{array}$ & ++ & +++ & ++ & ++ \\
\hline $\begin{array}{l}\text { Personnel } \\
\text { Management }\end{array}$ & + & ++ & + & +++ \\
\hline $\begin{array}{l}\text { Trading } \\
\text { business }\end{array}$ & +++ & ++ & + & + \\
\hline Finance & +++ & + & +++ & ++ \\
\hline Sociologists & + & ++ & + & +++ \\
\hline advertising & +++ & + & + & ++ \\
\hline
\end{tabular}

These tables illustrate that each direction is differently correlated with different types of innovations, which can contribute to the choice of direction for students to study in the magistracy.

Further, a few identified deficiencies in the training programs themselves, noted by employers, should be noted. The organization of innovative (scientific and technical) activity along with the laws governing entrepreneurial activity is regulated by certain documents of the state standardization system (GOST). Graduates of an economic university often learn about this only once they get to the enterprise. This provokes negative consequences in relationships with colleagues and lack of motivation. Educational programs in economics and management for the high-tech sector should form the necessary competencies in this direction, which will increase the value of a specialist in the labor market.

The consultants note the importance of distinguishing interests and the possibility of applicability of existing skills or matching the type of student character, this is the life cycle of an enterprise's products. For the high-tech sector, it is presented, as a rule, in full (research and production associations), although it can be distributed among various market entities: universities, research institutes, design and engineering bureaus, etc. Unfortunately, today we must admit that the end-toend system of the innovation process, starting from basic research and exploratory scientific work with the subsequent transition to applied and ending with the manufacture of prototypes with the setting of products for serial production, has largely turned out to be unsuitable for existing disparate business entities [6]. Nevertheless, future managers and economists need to know in advance which organizations to apply their knowledge to, and the university must timely adjust educational programs.

Separately, employers raised the issue of transforming the product life cycle in the new economic conditions caused by the development of public-private partnerships and technology transfer. Recently (starting from 2004), the transfer of technol- 
ogies created at the expense of the state to the militaryindustrial complex has increasingly provided a multiplier effect, influencing the general situation in the industry.

An important role in this is played by the format of publicprivate partnerships. The state in the person of the customer with the participation of private investors within the existing life cycles forms new "organizational and technical" structures that replace the usual forms. Table 2 summarizes such successful practices. Separately, the consultants noted the phase of the "decommissioning and disposal" phase of the life cycle. Given the enormous relevance of this issue for the Russian economy, universities do not train specialists who are properly versed in the intricacies of managing this activity.

TABLE II. SUCCESSFUL PRACTICES AND STAGES OF THE LIFE CYCLE

\begin{tabular}{|l|l|l|}
\hline $\begin{array}{c}\text { Life cycle } \\
\text { stage }\end{array}$ & \multicolumn{1}{|c|}{ Idea } & \multicolumn{1}{c|}{ Examples } \\
\hline Exploitation & $\begin{array}{l}\text { Conducting education, } \\
\text { training, retraining and } \\
\text { certification of personnel }\end{array}$ & $\begin{array}{l}\text { Learning Centers } \\
\text { Areva, Westinghouse, } \\
\text { GE }\end{array}$ \\
\hline Production & $\begin{array}{l}\text { Production of special } \\
\text { materials, parts, fasteners, etc. } \\
\text { (over 70\% in the interests of } \\
\text { the industry) }\end{array}$ & $\begin{array}{l}\text { OKB KP - cables for } \\
\text { special purposes, Red } \\
\text { Banner (for Almaz- } \\
\text { Antey) }\end{array}$ \\
\hline Development & $\begin{array}{l}\text { Testing complex } \\
\text { SP } \\
\text { Research Institute of } \\
\text { Sweden }\end{array}$ \\
\hline Study & $\begin{array}{l}\text { Production of prototypes, } \\
\text { breadboard models, samples ... }\end{array}$ & $\begin{array}{l}\text { LLC } \\
\text { Technologies - }\end{array}$ \\
& $\begin{array}{l}\text { Information and analytical } \\
\text { support of various processes } \\
\text { and projects of the industry }\end{array}$ & $\begin{array}{l}\text { Analytical Center RC } \\
\text { ITAR TASS }\end{array}$ \\
\hline
\end{tabular}

All groups participating in the survey consider it necessary to explain to students the scheme of work of enterprises during the entire period of study in relation to various disciplines of the curriculum. One of the best techniques can be considered a process approach, when the presented activity of each structural unit is accompanied by a certain set of incoming and outgoing information. This allows the student to understand in more detail its flows. At the same time, it is important to explain to students that education is somewhat universal because differences in the activities of enterprises that solve various problems within the life cycle are similar in many procedures and processes.

Forming the interaction between the university and the industrial enterprise, one must always remember the monetary component. Since recently the outflow of schoolchildren from universities to secondary schools and the difficulties of several universities with filling out programs have intensified, we agreed with the offer of employers to acquaint students with a career growth map. By adding to this information, the primary matrix of the distribution of responsibility, it is possible to form an understanding among students of their possible determination of their place in the structure of a virtual enterprise (Table 3).

A separate issue is the accessibility of communication between the student - a possible employee of the enterprise with a possible employer. Employers believe that a student who is in the process of his own career guidance should be familiar with the tactics of developing a training system in industry.

TABLE III. THE MATRIX OF THE DISTRIBUTION OF RESPONSIBILITY

\begin{tabular}{|c|c|c|c|c|c|}
\hline \multirow{2}{*}{$\begin{array}{c}\text { Buisness } \\
\text { process/ } \\
\text { functional }\end{array}$} & \multirow{2}{*}{$\begin{array}{c}\text { Name of } \\
\text { works }\end{array}$} & \multicolumn{4}{|c|}{ Directorate } \\
\hline & & $\begin{array}{c}\text { Com- } \\
\text { mercial }\end{array}$ & Technical & $\begin{array}{l}\text { Manufac- } \\
\text { turing }\end{array}$ & $\begin{array}{l}\text { Pro- } \\
\text { cure- } \\
\text { ment }\end{array}$ \\
\hline marketing & $\begin{array}{l}\text { Customer } \\
\text { Search }\end{array}$ & & & & \\
\hline \multirow[t]{5}{*}{$\begin{array}{l}\text { Work with } \\
\text { customer }\end{array}$} & $\begin{array}{l}\text { Application } \\
\text { development }\end{array}$ & & & & \\
\hline & \begin{tabular}{|l|}
$\mathrm{TCH}$ \\
issuance
\end{tabular} & & & & \\
\hline & $\begin{array}{l}\text { Conclusion } \\
\text { of an } \\
\text { agreement }\end{array}$ & & & & \\
\hline & $\begin{array}{l}\text { Opening } \\
\text { outfit }\end{array}$ & & & & \\
\hline & $\begin{array}{l}\text { Prepaid } \\
\text { expense }\end{array}$ & & & & \\
\hline \multirow[t]{2}{*}{ Design } & $\begin{array}{l}\text { Project } \\
\text { development }\end{array}$ & & & & \\
\hline & $\begin{array}{l}\text { Developmen } \\
t \text { of a set of } \\
\text { RKD }\end{array}$ & & & & \\
\hline \multirow[t]{2}{*}{$\begin{array}{l}\text { Technical } \\
\text { training }\end{array}$} & $\begin{array}{l}\text { CCI } \\
\text { development }\end{array}$ & & & & \\
\hline & $\begin{array}{l}\text { TD } \\
\text { development }\end{array}$ & & & & \\
\hline Procurement & $\begin{array}{l}\text { Procurement } \\
\text { of materials }\end{array}$ & & & & \\
\hline \multirow[t]{3}{*}{ Production } & Production & & & & \\
\hline & $\begin{array}{l}\text { Quality } \\
\text { assurance }\end{array}$ & & & & \\
\hline & $\begin{array}{l}\text { The signing } \\
\text { of the act of } \\
\text { delivery }\end{array}$ & & & & \\
\hline \multirow[t]{2}{*}{ Supply } & Shipment & & & & \\
\hline & payment & & & & \\
\hline
\end{tabular}

As an illustration, table 4 presents a typical program of one of the enterprises, which may have a role in the correct positioning of the graduate in the labor market.

TABLE IV. IMPROVING STAFFING IN THE ENTERPRISE

\begin{tabular}{|l|l|}
\hline \multicolumn{1}{|c|}{ Event } & \multicolumn{1}{|c|}{ The timing } \\
\hline $\begin{array}{l}\text { Analysis of management personnel, their distribution in the } \\
\text { nodal areas of work }\end{array}$ & Constantly \\
\hline $\begin{array}{l}\text { Determination of strategic directions for the training and } \\
\text { continuing education of specialists and skilled workers }\end{array}$ & Annually \\
\hline $\begin{array}{l}\text { Determining the need for specialists and workers in } \\
\text { accordance with the required level of knowledge, skills, the } \\
\text { necessary level of development of special abilities and } \\
\text { business qualities }\end{array}$ & Quarterly \\
\hline Organization of multi-level vocational education. & Quarterly \\
\hline $\begin{array}{l}\text { Monitoring and solving the problems of the most } \\
\text { appropriate use of graduates of educational institutions }\end{array}$ & Constantly \\
\hline $\begin{array}{l}\text { Preparation of events for staff development, planning and } \\
\text { effective implementation of a business career, continuous } \\
\text { professional development of personnel }\end{array}$ & $\begin{array}{l}\text { Once a half } \\
\text { year }\end{array}$ \\
\hline $\begin{array}{l}\text { Formation of a reserve of managers, personnel appraisal, } \\
\text { certification of specialists, improvement of the mechanism } \\
\text { for the selection and placement of personnel }\end{array}$ & $\begin{array}{l}\text { According to a } \\
\text { separate } \\
\text { schedule }\end{array}$ \\
\hline
\end{tabular}




\section{CONCLUSIONS}

Innovatively developing enterprises are actively looking for young people to implement ambitious plans. The problems of interaction between the real sector of the economy (industrial enterprises) and universities involved in training in the areas of economics and management are more pronounced than with technical universities. Changing the technological structure, technology transfer and other events in the real economy market are changing the basic organizational forms of production structures. As part of these changes, new previously little-studied stages appear, for example, disposal, which opens up prospects. On the other hand, it is worth remembering that changes should not lead to the breakdown of production and technological chains. The schemes of work (and management) of various enterprises in the life cycle of enterprises coincide in many respects. The student who has mastered the basic skills, easily adapts to various characteristics of the activity. For this, his training must be structured in a certain way.

Our studies allowed us to formulate some suggestions:

1) it is necessary to form the trajectory of students' movement according to innovative strategies of enterprises and types of innovations from the first courses of study on bachelor's programs;

2) include the basics of standardization in the curriculum for training managers, economists and financiers for industry;

3) inform students about the principles of development and training of personnel by industrial enterprises to encourage students to possible direct contact with a potential employer, given their standard training procedures.

\section{REFERENCES}

[1] Jamil Salmi. Sozdanie universitetov mirovogo klassa [Creation of worldclass universities]. tr. from English. M.: Publishing house "All World", 2009. 132 p. (In Russian)

[2] Suleimankadieva A.E., Fomicheva N.M. Evaluation of master's education in universities of St. Petersburg. Arhitektura universitetskogo obrazovaniya: sovremennye universitety $v$ usloviyah edinogo informacionnogo prostranstva Sbornik trudov III Nacional'noj nauchnometodicheskoj konferencii s mezhdunarodnym uchastiem. [Architecture of university education: modern universities in a single information space Proceedings of the III National Scientific and Methodological Conference with international participation]. Ed. I.A. Maksimtseva, V.G. Shubaeva, L.A. Mierin. 2019. Pp. 91-98. (In Russian)

[3] Suleimankadieva A.E., Petrov A.N., Fomicheva N.M. Prospects for the strategic development of master's education in the concept of "LIFELONG LEARNING". Mezhdunarodnaya konferenciya po myagkim vychisleniyam i izmereniyam [International Conference on Soft Computing and Measurements]. 2018. Vol. 2. P. 295-297. (In Russian)

[4] State website http://www.gks.ru

[5] Vetrova E.N., Bobrova O.S., Salienko N.V. Network forms of implementing educational programs: models and prospects. Arhitektura universitetskogo obrazovaniya: sovremennye universitety $v$ usloviyah edinogo informacionnogo prostranstva Sbornik trudov III Nacional'noj nauchno-metodicheskoj konferencii $s$ mezhdunarodnym uchastiem. [University Education Architecture: Modern Universities in a Single Information Space Proceedings of the III National Scientific and Methodological Conference with international participation]. Ed. I.A. Maksimtseva, V.G. Shubaeva, L.A. Mierin. 2019. Pp. 396-401. (In Russian)

[6] Vashchillo A.A., Vetrova E.N. Features of the interaction of the university and employers on the example of radio-electronic industry enterprises. Sotrudnichestvo universitetov $i$ rabotodatelej $s$ cel'yu obespecheniya kachestva i aktual'nosti obrazovaniya sbornik nauchnyh statej. [Cooperation between universities and employers in order to ensure the quality and relevance of education collection of scientific articles]. St. Petersburg, 2018. Pp. 109-114. (In Russian) 